\title{
Microbial Glycosidases for Wine Production
}

\author{
Sergi Maicas * and José Juan Mateo
}

Departament de Microbiologia i Ecologia, Universitat de València, Burjassot 46100, Spain; jjmateo@uv.es

* Correspondence: sergi.maicas@uv.es; Tel.: +34-96-3543214

Academic Editor: Shao Quan Liu

Received: 12 May 2016; Accepted: 26 July 2016; Published: 2 August 2016

\begin{abstract}
Winemaking is a complex process involving the interaction of different microbes. The two main groups of microorganisms involved are yeasts and bacteria. The yeasts present in spontaneous fermentation may be divided into two groups: the Saccharomyces yeasts, particularly S. cerevisiae; and the non-Saccharomyces yeasts, which include members of the genera Rhodotorula, Pichia, Candida, Debaryomyces, Metschtnikowia, Hansenula, and Hanseniaspora. S. cerevisiae yeasts are able to convert sugar into ethanol and $\mathrm{CO}_{2}$ via fermentation. They have been used by humans for thousands of years for the production of fermented beverages and foods, including wine. Their enzymes provide interesting organoleptic characteristics in wine. Glycosidases with oenological implications have been widely reported in yeasts, bacteria, and fungi. $\beta$-Glucosidase activity is involved in the release of terpenes to wine, thus contributing to varietal aroma. $\alpha$-Rhamnosidase, $\alpha$-arabinosidase, or $\beta$-apiosidase activities have also been reported to contribute to the wine production process. Oenococcus oeni (a lactic acid bacteria present in wine) also has numerous glycosidases, and their activities contribute to the liberation of several aromatic compounds which contribute to floral and fruity wine characteristics.
\end{abstract}

Keywords: non-Saccharomyces yeasts; malolactic bacteria; wine; flavor; $\beta$-glucosidase; $\beta$-xylosidase

\section{Introduction}

Annual global wine production is about 275 million $\mathrm{hL}$, according to the statistical survey conducted by the International Organization of Vine and Wine (OIV) (Figure 1).
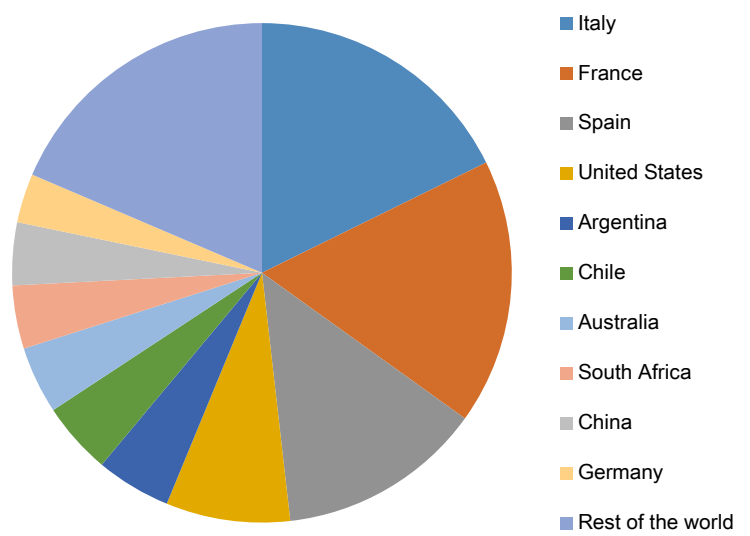

Figure 1. World wine production (2015).

European countries (mainly France, Italy, and Spain) lead the ranking, producing together about 133 million $\mathrm{hL}$. The United States (22 million $\mathrm{hL}$ ) is the other large scale wine producer, although there are a huge number of other countries reporting wine production [1]. 
Yeasts conduct the alcoholic fermentation in wine, mainly converting sugars to ethanol and carbon dioxide. Grape musts naturally contain a mixture of yeast and bacteria species, and wine fermentation is not a "single-species" fermentation. The dominance of the yeast Saccharomyces cerevisiae (inoculated or indigenous) in the fermentation is expected and desired. However, the indigenous non-Saccharomyces yeasts-already present in the must, and often in greater numbers than S. cerevisiae-are adapted to the specific environment and are in an active growth state, which gives them a competitive edge [2]. It is well established that wine fermentations, as conducted by traditional methods (without inoculation), are not the result of the action of a single species or a single strain. Rather, the final products result from the combined actions of several yeast and bacteria species which grow in succession throughout the fermentation process. The isolation and identification of yeasts from grape surfaces, and quantitative data on the ecology of grape yeasts have concluded that the isolation process of the total yeast population from the grapes is complex and dependent on many factors [3,4]. Fermentations are initiated by the growth of various species of Candida, Debaryomyces, Hanseniaspora, Hansenula, Kloeckera, Metschnikowia, Pichia, and Torulaspora. Their growth is generally limited to the first two or three days of fermentation, after which they die off. Subsequently, the most strongly fermenting and more ethanol-tolerant species of Saccharomyces take over the fermentation [5]. Non-Saccharomyces yeasts, as the name suggests, refers to all yeast species found in wine production barring S. cerevisiae, with the proviso that this only includes yeast with a positive role in wine production. Recognized spoilage yeasts, such as Dekkera/Brettanomyces, are normally left out of this description [6].

Although most fields of research are often focused primarily on S. cerevisiae, non-Saccharomyces research can benefit from the techniques and knowledge developed by the $S$. cerevisiae and other yeast researchers [2]. S. cerevisiae yeasts are able to convert sugar into ethanol and $\mathrm{CO}_{2}$ via fermentation. This yeast is adapted to the harsh conditions in grape musts and grapes (high sugar concentration, increasing alcohol concentration, acidity, presence of sulfites, anaerobiosis, and the progressive depletion of essential nutrients, such as nitrogen, vitamins, and lipids). However, S. cerevisiae is not only responsible for the metabolism of grape sugar to alcohol and $\mathrm{CO}_{2}$, but has an equally important role to play in the formation of secondary metabolites, as well as in the conversion of grape aroma precursors to varietal wine aromas [5,7-10]. In the past, the influence of non-Saccharomyces yeasts in wine was restricted and even eliminated by inoculation with pure $S$. cerevisiae cultures because they have long been regarded as spoilage yeasts [11]. However, in the past three decades, great interest has grown in the potential beneficial role of non-Saccharomyces yeasts in wine biotechnology [3,4]. It has been shown that some of the metabolites that these yeasts produce may be beneficial and may contribute to the complexity of the wine when they are used in mixed fermentations with S. cerevisiae cultures [12,13]. It is believed that when pure non-Saccharomyces yeasts are cultivated with S. cerevisiae strains, their negative metabolic activities may not be expressed or could be modified by the metabolic activities of the S. cerevisiae strains [14]. Several strains belonging to different non-Saccharomyces species have been extensively studied in relation to the formation of some metabolic compounds affecting the bouquet of the final product. Moreover, some of these yeasts showed positive oenological properties, and their use in the alcoholic fermentations has been suggested to enhance the aroma and flavor profiles. The non-Saccharomyces yeasts have the capability to produce and secrete enzymes in the wine, such as $\beta$-glucosidases, which release monoterpenes derived from their glycosylated form. These compounds contribute to the higher fruit-like characteristic of the final product.

Malolactic fermentation (MLF) is an important secondary reaction in winemaking, and generally occurs just after the alcoholic fermentation has been completed. It involves the growth of particular species of lactic acid bacteria (Lactobacillus, Pediococcus, Leuconostoc, and, predominantly, Oenococcus). The first reason for inducing MLF is deacidification of the wine. In addition, MLF influences the microbiological stability and organoleptic quality of the wine $[15,16]$. Oenococcus oeni (formerly Leuconostoc oenos) [17] is the major bacterial species found in wines during MLF, and is well adapted to the low $\mathrm{pH}$ and high ethanol concentration of wine [18]. 
Glycosidases with oenological implications have been widely reported in yeasts, bacteria and fungi [19-21].

\section{Yeast Glycosidases}

Yeasts of the Hansenula species isolated from fermenting must were reported to have an inducible $\beta$-glucosidase activity, but this enzyme was inhibited by glucose [19]. Other yeast strains, such as Candida molischiana [22] and C. wickerhamii [23] also have activities towards various $\beta$-glucosides, and they were not strongly influenced by the nature of aglycon [20]. $\beta$-Glucosidase from C. molischiana was immobilized in Duolite A-568 resin, showing similar physicochemical properties to those of free enzyme. The immobilized enzyme was found to be very stable under wine conditions, and could be used repeatedly for several hydrolyses of bound aroma [24]. Endomyces fibuliger also produces extracellular $\beta$-glucosidase when grown in malt extract broth [25].

Screening 370 strains belonging to 20 species of yeasts, all of the strains of the species Debaryomyces castelli, D. hansenii, D. polymorphus, Kloeckera apiculate, and Hansenula anomala showed $\beta$-glucosidase activity [26]. A strain of $D$. hansenii exhibited the highest exocellular activity, and some wall-bound and intracellular activity. Its synthesis, occurring during exponential growth, was enhanced by aerobic conditions and was repressed by high glucose concentration. The optimum condition for this enzyme was $\mathrm{pH} 4.0-5.0$ and $40^{\circ} \mathrm{C}$. This enzyme was immobilized using a one-step procedure on hydroxyapatite. The immobilized enzyme exhibited a lower activity than the purified free enzyme, but was much more stable than the enzyme in cell-free supernatant [27]. These studies have shown the ability of several wine yeasts to hydrolyze terpenoids, norisoprenoids and benzenoids glycosides; among wine yeasts, Hanseniaspora uvarum was able to hydrolyze both glycoconjugated forms of pyranic and furanic oxides of linalool [28-30]. Other authors have also shown the important role of non-Saccharomyces species in releasing the glycoside-bound fraction of grape aroma components [30-32].

Finally, the situation regarding S. cerevisiae is more complex, because this yeast is capable of modifying the terpenic profile of the wine; thus, it can produce citronellol from geraniol and nerol; the intensity of this transformation depends on the yeast strain used [33,34]. Other authors propose a more complex scheme: geraniol was transformed by these yeasts into geranyl acetate, citronellyl acetate, and citronellol, while nerol was transformed into neryl acetate; in addition, geraniol was transformed into linalool and nerol was cyclized to $\alpha$-terpineol at must $\mathrm{pH}$ [35].

Few data are available regarding glycosidase activities of oenological yeast strains and the technological properties of the enzymes. Low $\alpha$-rhamnosidase, $\alpha$-arabinosidase, or $\beta$-apiosidase activities were detected in S. cerevisiae [36]. Nevertheless, data on $\beta$-glucosidase activity on Saccharomyces are contradictory. First results showed that these yeasts had a very low activity [37], but Delcroix et al. [36] found three enological strains showing high $\beta$-glucosidase activity. On the other hand, Darriet et al. [38] have shown that oxidases located in the periplasmic space of a strain of $S$. cerevisiae were able to hydrolyze monoterpene glucosides of Muscat grapes; they also found that the activity of this $\beta$-glucosidase was glucose-independent. Mateo and Di Stefano [39] detected $\beta$-glucosidase activity in different Saccharomyces strains on the basis of its hydrolytic activity on $p$-nitrophenyl- $\beta$-D-glucoside ( $p$ NPG) and the terpene glucosides of Muscat juice (Table 1).

This enzymatic activity is induced by the presence of bound $\beta$-glucose as a carbon source in the medium and seems to be a characteristic of the yeast strain. This $\beta$-glucosidase, associated with the yeast cell wall, is quite glucose-independent but is inhibited by ethanol. These results could open new pathways regarding other glycosidase activities in S. cerevisiae; $\alpha$-rhamnosidase, $\alpha$-arabinosidase, or $\beta$-apiosidase activities could be induced in wine yeast by changing the composition of the medium including inductive compounds, as well as in filamentous fungi [40,41]. 
Table 1. Results obtained by hydrolysis of terpene glycosides treated with different enzymatic preparations (200 $\mu \mathrm{L}$ of each commercial preparation). Data are normalized to 100 in untreated wines.

\begin{tabular}{|c|c|c|c|c|c|c|c|c|}
\hline \multirow{2}{*}{ No. } & \multirow{2}{*}{ Terpenes } & \multirow{2}{*}{ Grape Skin } & \multirow{2}{*}{$\begin{array}{c}\text { Saccharomyces cerevisiae S1U } \\
\text { Glucosidase [39] }\end{array}$} & \multirow{2}{*}{ Klerzyme $200^{\circledR} *$} & \multicolumn{2}{|c|}{ Exogenous Glycosidases } & \multicolumn{2}{|c|}{ Hemicellulase } \\
\hline & & & & & Pectinol $C^{\circledR *}$ & Rohapect $C^{\circledR *}$ & Sweet Wine * & Dry Wine * \\
\hline 1 & trans-Furan linalool oxide & 108.2 & 122.9 & 247.3 & 174.3 & 943.1 & 109.7 & 129.7 \\
\hline 2 & cis-Furan linalool oxide & 124.3 & 296.8 & 149.2 & 133.8 & 456.1 & 87.0 & 117.6 \\
\hline 3 & Linalool & 101.2 & 204.6 & 113.6 & 111.0 & 187.8 & 107.5 & 108.8 \\
\hline 4 & Hotrienol & & & 93.3 & & 113.2 & 130.8 & 87.1 \\
\hline 5 & Neral & & & & & & & \\
\hline 6 & $\alpha$-Terpineol & & 230.0 & 150.8 & & 190.8 & 113.8 & 141.7 \\
\hline 7 & Geranial & & & & & & & \\
\hline 8 & trans-Pyran linalool oxide & 124.9 & & 109.3 & 109.1 & 113.1 & 104.2 & 104.4 \\
\hline 9 & cis-Pyran linalool oxide & 104.5 & & 88.9 & & 136.3 & 111.4 & 98.0 \\
\hline 10 & Citronellol & 177.6 & 176.6 & 551.9 & 239.8 & 131.8 & 146.5 & 335.4 \\
\hline 11 & Nerol & 593.0 & 847.6 & 424.5 & 720.0 & 1173.2 & 190.6 & 642.0 \\
\hline 12 & Geraniol & 381.9 & 833.4 & 491.8 & 633.2 & 806.2 & 107.0 & 359.1 \\
\hline 13 & Diol I & 104.2 & 91.4 & 151.9 & 112.7 & 152.3 & 113.8 & 98.0 \\
\hline 14 & Endiol & & 133.0 & & & & & \\
\hline 15 & Diol II & 101.4 & 112.5 & 174.7 & 114.0 & 124.3 & 100.1 & 97.6 \\
\hline 16 & Hydroxy-citronellol & 152.6 & 159.0 & & 178.4 & 552.9 & & \\
\hline 17 & 8-Hydroxy-dihydro-linalool & 275.9 & 230.8 & 152.9 & 397.6 & & 105.9 & 93.2 \\
\hline 18 & Hydroxy-nerol & & 141.4 & & & & & \\
\hline 19 & trans-8-Hydroxy-linalool & 133.4 & 466.0 & 1343.0 & 431.5 & & & \\
\hline 20 & Hydroxy-geraniol & & 140.2 & & & 475.0 & & \\
\hline 21 & cis-8-Hydroxy-linalool & 271.8 & 688.9 & 4083.0 & 990.0 & 916.9 & & \\
\hline 22 & Geranic acid & 362.6 & 522.8 & & 410.2 & & & \\
\hline
\end{tabular}




\section{Bacterial Glycosidases}

Oenococcus oeni is the species generally recognized as beneficial for final aroma compounds in wine $[42,43]$. This bacterium is involved in the malolactic fermentation (MLF), the conversion of the malic acid in wine to lactic acid and carbon dioxide. This reaction, generally associated with a finally equilibrated good wine [44], can also be performed by other lactic acid bacteria (LAB) (Leuconostoc, Lactobacillus and Pediococcus), although it is generally performed by O. oeni strains [45]. Recent information is available regarding the $\beta$-glucosidase activity of LAB involved in wine-making. Nowadays, it is known that $O$. oeni has numerous glycosidases [46], and their activities contribute to the liberation of several aroma compounds, including monoterpenes, norisoprenoids, and aliphatic compounds, which contribute to floral and fruity wine characteristics [47-49]. It has been demonstrated that O. oen $i$ was able to cleave the glucose moiety from the major red wine anthocyanin, malvidin-3-glucoside, to use it as a carbon source. The release of glycosylated volatile precursors in Tannat wine was also observed [21], and only minimal O. oeni glycosidase activity was noted in Viognier glycosidic extracts [50]. The effective $\beta$-glucosidase activity of some strains of $O$. oeni has been previously reported [46-52]. Mansfield et al. [53] also detected the production of $\beta$-glucosidase enzymes in several strains of $O$. oeni, although cultures of the same strains failed to hydrolyze native grape glycosides.

The study of the hydrolysis of wine aroma precursors (linalool, $\alpha$-terpineol, nerol, and geraniol) during MLF has been carried out with some O. oeni starter cultures in model wine solutions by Ugliano et al. [48]. The liberation of glycosidically-bound aroma compounds was assessed for various strains which also performed the MLF. Although the quantity of released precursors was strain-dependent, the large release of glycosylated aroma compounds observed during their experiments suggests that O. oeni can actively contribute to the changes in the sensory characteristics of wine after MLF through the hydrolysis of aroma precursors. Some studies describing the characterization and purification of $\beta$-glucosidase from native crude extracts of $O$. oeni strains have been reported [54-65]. There are also 17 different species of Lactobacillus associated with winemaking, either associated with the grapes or isolated at different stages of alcoholic fermentation or MLF. Some of these strains possess enzyme-encoding genes important for the production of wine aroma compounds such as glycosidase [66].

$\alpha$-L-Rhamnosidases also play an important role in the hydrolysis of glycosylated aroma compounds (especially terpenes) from wine. Although several authors have demonstrated the enological importance of fungal rhamnosidases, the information on bacterial enzymes in this context is still limited to Pediococcus acidilactici $[67,68]$.

\section{Fungal Glycosidases}

Considering that the enzymatic systems of grapes are not able to hydrolyze terpene glycosides in grape juice or wine, more studies are demanded regarding the ability of yeasts and LAB to yield all the enzymes involved in this process. Several exogenous enzymes, mainly with a fungal origin, have been developed to liberate terpenes in wines. They are the named exogenous (fungal) glycosidases. Comparing 34 different enzymatic preparations, the most suitable ones to be used during the winemaking process are those which posses all $\beta$-D-glucopyranosidase, $\alpha$-L-arabinofuranosidase, $\alpha$-L-rhamnopyranosidase, and $\beta$-D-apiofuranosidase activities (Table 1).

With regard to the enological uses of exogenous enzymes, the non-selectivity of the glycosidases in Rohapect $\mathrm{C}$, together with its relative tolerance to ethanol, suggest a feasible application in releasing any glycosidically-bound terpenes present in wines. Even for this purpose, however, the high $\mathrm{pH}$ values required for the enzymes in this preparation to function effectively (5.0-6.0) limits their practical utility. The great sensitivity of the $\beta$-glucosidase of Rohapect $C$ and several other commercial non-plant glycosidases to glucose excludes any application of these enzymes in juice processing [69].

Aspergillus niger $\beta$-glucosidases from two different commercial preparations do not show the same hydrolysis rates towards linalyl $\beta$-D-glucosides. After $24 \mathrm{~h}$ of incubation, $\beta$-glucosidase from 
the Hemicellulase preparation (Gist Brocades, France) hydrolyzed the substrate completely, whereas $\beta$-glucosidase from the Pectinol C preparation (Röhm, Germany) hydrolyzed only one third of it. $\alpha$-Terpenyl $\beta$-D-glucoside was not a substrate for $A$. niger $\beta$-glucosidase from Pectinol preparation; however, this substrate was hydrolyzed by $A$. niger $\beta$-glucosidase from Hemicellulase preparation. Such variations in both commercial enzymatic preparations are probably due to the use of different strains of $A$. niger [37].

The availability of purified enzymes, synthetic substrates, and suitable analytical methods are needed for rigorous progress in the field of the enzymatic hydrolysis of terpenyl glycosides [70-75]. Enzymes have been isolated from fungal enzymatic preparations, vegetal extracts, or synthetic culture media inoculated with fungal cultures, and have been purified by different chromatographic techniques (gel filtration, ion-exchange chromatography, affinity chromatography, chromatofocusing).

$\beta$-Apiosidase has been partially purified by filtration chromatography on Ultrogel AcA 44 and ion exchange chromatography on diethylaminoethyl (DEAE)-Sepharose CL-6B from A. niger cultures. The $(1 \rightarrow 6)$ sugar linkage of the apiosylglucosides of nerol, geraniol, and pyran linalool oxide was cleaved by the enzyme with liberation of the corresponding monoglucosides. Furthermore, apiosylglucosides of furan linalool oxide did not appear to be good substrates for $\beta$-apiosidase, unlike other apiosylglucosides. The production of the enzyme by $A$. niger is inducible, as it is only produced when apiin (2-O- $\beta$-D-apiofuranosyl- $\beta$-D-glucoside of apigenin) was present in the culture medium as the carbon source. In the same way, peptone $(2 \% w / v)$ and Tween $80(0.15 \% v / v)$ activate $\beta$-apiosidase synthesis. With regard to the activity, the optimum $\mathrm{pH}$ and temperature were 5.6 and $50^{\circ} \mathrm{C}$, respectively, and different ions have inhibitory effects on $\beta$-apiosidase activity. Conversely, the enzyme was inhibited neither by glucose nor by ethanol [41].

An $\alpha$-L-arabinofuranosidase from $A$. niger was purified from a commercial crude preparation of Hemicellulase REG2 by gel filtration on Ultrogel AcA 44, by ion exchange chromatography on DEAE-Sepharose CL-6B, and by affinity chromatography on Concanavalin A-Ultrogel AcA 22. The optimum $\mathrm{pH}$ of the enzyme was 3.9, and the temperature of maximal activity $60{ }^{\circ} \mathrm{C}$. This arabinosidase was active against monoterpenyl $\alpha$-L-arabinofuranosylglucosides from grapes by liberating monoterpenyl $\beta$-D-glucosides and arabinose, regardless of the structure of the aglycon moiety [37]. This enzyme has been immobilized on chitosan by conjugation; this method proved to be the better one, as it ensures good biocatalyst activity and better stability than reported for the free enzyme [75].

An $\alpha$-L-rhamnopyranosidase from a naringinase commercial preparation from Penicillium sp. was free from contaminating $\beta$-D-glucosidase activity by chromatofocusing on PBE 94 using a $\mathrm{pH}$ gradient. Rhamnosidase isoenzymes were eluted at $\mathrm{pH} 6.2$ and 5.7, respectively [71].

A strain of $A$. niger excreted a $\beta$-glucosidase into the medium which was partially purified by affinity chromatography. The enzyme was found to hydrolyze natural glycosides and was competitively inhibited by glucose. The $\mathrm{pH}$ optimum was 3.4, and ethanol enhanced the activity. Immobilization of fungus using $\mathrm{Ca}^{2+}$ alginate beads enabled an increase in enzyme production in a continuous fermentation [76,77]. Later, an endo- $\beta$-glucosidase from $A$. niger was immobilized to acrylic beads [40] or to $\gamma$-alumina activated with dodecamethylendiamine and glutaraldehyde in sequence [78]. GC-MS analysis of the wines indicated that the enzyme treatment increased concentrations of free monoterpene alcohols.

Aspergillus oryzae was found to secrete two distinct $\beta$-glucosidases when it was grown in liquid culture. The major form was highly inhibited by glucose, but the minor form (which was induced on quercitin) exhibited high tolerance to glucose or gluconolactone inhibition. The enzyme was optimally active at $50{ }^{\circ} \mathrm{C}$ and $\mathrm{pH}$ 5.0. It exhibits exoglucanase activity and was able to release flavor compounds [79]. Similar results were obtained in A. niger [80]. These enzymes are present only in low quantities in the majority of commercial fungal enzymatic preparations, mainly regarding $\beta$-D-apiosidase activity [41]. 
Determination of free volatile compound terpenols, norisoprenoids, and volatile phenols indicates that concentrations in enzyme-treated wines highly increase, not only in aromatic varieties, but also in neutral ones. Enhancements widely varied according to the original grapes, from $265 \%$ to $2.000 \%$ [81]. Nevertheless, multiple forms of glycosidases could be present in an enzymatic preparation. So, chromatofocusing of a crude enzyme preparation from $A$. niger on PBE 94 showed the presence of multiple forms of $\beta$-apiosidase, $\beta$-glucosidase, $\alpha$-rhamnosidase, and $\alpha$-arabinosidase [82].

Enzymes are effective for some days after their addition to the wine, while glycosidic precursors remain almost unchanged throughout fermentation. The method used to enrich wine in volatile compounds is only effective when dry wines are used, because $\beta$-glucosidase is heavily inhibited by glucose in fungal enzymatic preparations. The hydrolysis of terpene glycosides is not completed in sweet wines obtained from Muscat de Frontignan grapes, due to inhibition of $\beta$-glucosidase by the presence of glucose [37].

\section{Conclusions}

The presence of terpenes, in their different forms, in grape juices and wines represents great potential as a means to increase the varietal characteristics of the wines, contributing the final product with higher fruit-like characteristics. Some microorganisms have the capability to produce and secrete enzymes in the wine, such as $\beta$-glucosidases, which contribute to the release of monoterpenes derived from their glycosylated form. These compounds add a fruit-like characteristic to the final wine. Researchers have sufficient information and tools to study the presence of terpenes and their evolution in grape juices and wines, but it is not yet possible to translate all of the acquired knowledge to the wineries, because an efficient methodology to improve the terpene content of all the wines present in the market has not been found.

Several approaches through genetic engineering techniques will doubtless be used in the near future to overcome- by using recently discovered glucosidases-the limitations on the exploitation of the glycosylated aroma source in the processing of fruit juices and derived beverages.

The production of wine is generally conducted by yeasts. Their enzymes provide interesting organoleptic characteristics to the wine: glycosidases are key enzymes in the process. Monoterpenes, norisoprenoids, benzene derivatives, and aliphatic components are involved in Muscat grape juice and wine. These compounds have been detected in a glycosidically-bound form: therefore, the liberation could enhance wine aroma. The latest results in this area open the possibility of the use of new strains to be used to improve the aromatic characteristics of the wines, in regard to the liberation of terpenes.

On the other hand, the construction of fungal strains expressing these proteins involved in flavor liberation may enable the production of tailor-made glycosidases without undesirable activities. A lot of work remains to be done to obtain a methodology, probably of enzymatic nature, which allows a wine-consumer's sense of smell to appreciate the whole organoleptic richness of the product that they have in their hands or in their mouths. Research in yeast and fungal glycosidasic enzymes is extensive. However, we are still far from understanding the complexity of bacterial glycoside metabolism.

The liberation of glycosidically-bound aroma compounds has been proven for various bacterial strains which also performed the MLF. Although the quantity of released precursors was strain-dependent, the large release of glycosylated aroma compounds reported suggests that O. oeni can actively contribute to the changes of sensory characteristics of wine after MLF through the hydrolysis of aroma precursors. Therefore, further work will be necessary to understand the functionality and metabolic relevance of LAB glycosidases. A comprehensive study of enzyme characteristics is required to achieve a better understanding of the principles of bacterial glycosidase metabolism.

Further work remains to be done to fully understand the capabilities of several microorganisms to enrich all the organoleptic aspects included in wine.

Acknowledgments: The Universitat de València kindly supported this work included in the project "Identification and biotechnological characterization of yeasts isolated from agrifood residues of the Valencian Community", grants INV-AE-336499 and AICO-2016-079. 
Conflicts of Interest: The authors declare no conflict of interest.

\section{Abbreviations}

The following abbreviations are used in this manuscript:

$\begin{array}{ll}\text { DEAE } & \text { DiEthylAminoEthyl } \\ \text { LAB } & \text { Lactic Acid Bacteria } \\ \text { MLF } & \text { MaloLactic Fermentation } \\ p \text { NPG } & p \text {-NitroPhenyl- } \beta \text {-D-Glucoside }\end{array}$

\section{References}

1. International Organisation of Vine and Wine. Available online: http://www.oiv.int (accessed on 8 March 2016).

2. Cray, J.A.; Bell, A.N.W.; Bhaganna, P.; Mswaka, A.Y.; Timson, D.J.; Hallsworth, J.E. The biology of habitat dominance; can microbes behave as weeds? Microb. Biotechnol. 2013, 6, 453-492. [CrossRef] [PubMed]

3. Gil, J.V.; Mateo, J.J.; Jiménez, M.; Pastor, A.; Huerta, T. Aroma compounds in wine as influenced by apiculate yeasts. J. Food Sci. 1996, 61, 1247-1249. [CrossRef]

4. Mendes-Ferreira, A.; Clımaco, M.C.; Mendes-Faia, A. The role of non-Saccharomyces species in releasing glycosidic bound fraction of grape aroma components-a preliminary study. J. Appl. Microbiol. 2001, 91, 67-71. [CrossRef] [PubMed]

5. Pretorius, I.S. The genetic analysis and tailoring of wine yeasts. In Topics in Current Genetics; de Winde, J.H., Ed.; Springer-Verlag: Berlin, Germany, 2003; Volume 2, pp. 99-141.

6. Maicas, S.; Mateo, J.J. Hydrolysis of terpenyl glycosides in grape juice and other fruit juices, a review. Appl. Microbiol. Biotechnol. 2005, 67, 322-355. [CrossRef] [PubMed]

7. Pretorius, I.S.; van der Westhuizen, T.J.; Augustyn, O.P.H. Yeast biodiversity in vineyards and wineries and its importance to the South African wine industry. S. Afr. J. Enol. Vitic. 1999, 20, 61-74.

8. Swiegers, J.H.; Pretorius, I.S. Yeast modulation of wine flavor. Adv. Appl. Microbiol. 2005, 57, 131-175. [PubMed]

9. Swiegers, J.H.; Bartowsky, E.J.; Henschke, P.A.; Pretorius, I.S. Yeast and bacterial modulation of wine aroma and flavour. Aust. J. Grape Wine Res. 2005, 11, 139-173. [CrossRef]

10. Swiegers, J.H.; Kievit, R.L.; Siebert, T.; Lattey, K.A.; Bramley, B.R.; Francis, I.L.; King, E.S.; Pretorius, I.S. The influence of yeast on the aroma of Sauvignon blanc wine. Food Microbiol. 2009, 26, 204-211. [CrossRef] [PubMed]

11. Andorrà, I.; Berradre, M.; Rozès, N.; Mas, A.; Guillamón, J.M.; Esteve-Zarzoso, B. Effect of pure and mixed cultures of the main yeast species on grape must fermentation. Eur. J. Food Res. Technol. 2010, 231, 215-224. [CrossRef]

12. Mateo, J.J.; Jiménez, M.; Huerta, T.; Pastor, A. Contribution of different yeasts isolated from musts of Monastrell grapes to the aroma of wine. Int. J. Food Microbiol. 1991, 14, 153-160. [CrossRef]

13. Rodríguez, M.E.; Lopes, C.A.; Barbagelata, R.J.; Barda, N.B.; Caballero, A.C. Influence of Candida pulcherrima Patagonian strain on alcoholic fermentation behaviour and wine aroma. Int. J. Food Microbiol. 2010, 138, 19-25. [CrossRef] [PubMed]

14. Ciani, M.; Maccarelli, F. Oenological properties of non-Saccharomyces yeasts associated with wine-making. World J. Microbiol. Biotechnol. 1998, 14, 199-203. [CrossRef]

15. Davis, C.R.; Wibowo, D.; Fleet, G.H.; Lee, T.H. Properties of wine lactic acid bacteria, their potential enological significance. Am. J. Enol. Vitic. 1988, 39, 290-301.

16. Kunkee, R.E. A heady concoction of alcoholic and malolactic fermentations. Nat. Biotechnol. 1997, 15, $224-225$. [CrossRef] [PubMed]

17. Dicks, L.M.T.; Dellaglio, F.; Collins, M.D. Proposal to reclassify Leuconostoc oenos as Oenococcus oeni [corrig.] gen. nov., comb. nov. Int. J. Syst. Bacteriol. 1995, 45, 395-397. [CrossRef] [PubMed]

18. Wibowo, D.; Eschenbruch, R.; Davis, C.R.; Lee, T.H. Occurrence and growth of lactic acid bacteria in wine, a review. Am. J. Enol. Vitic. 1985, 36, 302-313.

19. Grossmann, M.; Rapp, A.; Rieth, W. Enzymatische Freisetzung gebundener Aromastoffe in wein. Dtsch. Lebensm. Rdsch. 1987, 83, 7-12. 
20. Gunata, Z.; Brillouet, J.M.; Voirin, S.; Baumes, B.; Cordonnier, R. Purification and some properties of an $\alpha$-L-arabinofuranosidase from Aspergillus niger. Action on grape monoterpenyl arabinofuranosyl glucosidases. J. Agric. Food Chem. 1990, 38, 772-776. [CrossRef]

21. Boido, E.; Lloret, A.; Medina, K.; Carrau, F.; Dellacasa, E. Effect of $\beta$-glucosidase activity of Oenococcus oeni on the glycosylated flavor precursors of Tannat wine during malolactic fermentation. J. Agric. Food Chem. 2002, 50, 2344-2349. [CrossRef] [PubMed]

22. Gonde, P.; Ratomahenina, R.; Arnaud, A.; Galzy, P. Purification and properties of the exocellular $\beta$-glucosidase of Candida wickerhamii (Zikes) Meyer and Yarrow capable of hydrolysing soluble cellodextrines. Can. J. Biochem. Cell Biol. 1985, 63, 1160-1166. [CrossRef]

23. Leclerc, M.; Arnaud, A.; Ratomahenina, R.; Galzy, P.; Nicolas, M. The enzyme system in a strain of Candida wickerhamii Meyer and Yarrow participating in the hydrolysis of cellodextrins. J. Gen. Appl. Microbiol. 1984, 30, 509-521. [CrossRef]

24. Gueguen, Y.; Chemardin, P.; Pien, S.; Arnaud, A.; Galzy, P. Enhancement of aromatic quality of Muscat wine by the use of immobilized $\beta$-glucosidase. J. Biotechnol. 1997, 55, 151-156. [CrossRef]

25. Brimer, L.; Nout, M.J.R.; Tuncel, G. Glycosidase (amygdalase and linamarase) from Endomyces fibuliger (LU677), formation and crude enzyme properties. Appl. Microbiol. Biotechnol. 1998, 49, 182-188. [CrossRef] [PubMed]

26. Rosi, I.; Vinella, M.; Domizio, P. Characterization of $\beta$-glucosidase activity in yeasts of enological origin. J. Appl. Bacteriol. 1994, 77, 519-527. [CrossRef] [PubMed]

27. Riccio, P.; Rossano, R.; Vinella, M.; Domizio, P.; Zito, F.; Sanseverino, F.; D’Elia, A.; Rosi, I. Extraction and immobilization in one step of two $\beta$-glucosidases released from a yeast strain of Debaryomyces hansenii. Enzym. Microbiol. Technol. 1999, 24, 123-129. [CrossRef]

28. Fernandez, M.; di Stefano, R.; Briones, A. Hydrolysis and transformation of terpene glycosides from Muscat must by different yeast species. Food Microbiol. 2003, 20, 35-41. [CrossRef]

29. Sabel, A.; Martens, S.; König, H.; Claus, H. Wickerhamomyces anomalus AS1: A new strain with potential to improve wine aroma. Ann. Microbiol. 2014, 64, 483-491. [CrossRef]

30. Schwentke, J.; Sabel, A.; Petri, A.; König, H.; Claus, H. The yeast Wickerhamomyces anomalus AS1 secretes a multifunctional exo- $\beta-1,3-$ glucanase with implications for winemaking. Yeast 2014, 31, 349-359. [CrossRef] [PubMed]

31. Esteve, B.; Manzanares, P.; Ramon, D.; Querol, A. The role of non-Saccharomyces yeasts in industrial wine making. Int. Microbiol. 1998, 1, 143-148.

32. Mendes, A.; Climaco, M.C.; Mendes, A. The role of non-Saccharomyces species in releasing glycosidic bound fraction of grape aroma components-A preliminary study. J. Appl. Microbiol. 2001, 91, 67-71. [CrossRef]

33. Dugelay, I.; Gunata, Z.; Sapis, J.C.; Baumes, R.; Bayonove, C. Etude de l'origine du citronellol dans les vins. J. Int. Sci. Vigne Vin 1992, 26, 177-184.

34. Hernandez, L.F.; Espinosa, J.C.; Fernandez, M.; Briones, A. $\beta$-Glucosidase activity in a Saccharomyces cerevisiae wine strain. Int. J. Food Microbiol. 2003, 80, 171-176. [CrossRef]

35. Di Stefano, R.; Magiorotto, G.; Gianotti, S. Transformazioni di nerolo e geraniolo indotte dai lieviti. Riv. Vitic. Enol. 1992, 42, 43-49.

36. Delcroix, A.; Gunata, Z.; Sapis, J.C.; Salmon, J.M.; Bayonove, C. Glycosidase activities of three enological yeast strains during wine making. Effect on the terpenol content of Muscat wine. Am. J. Enol. Viticult. 1994, 45, 291-296.

37. Gunata, Z.; Dugelay, I.; Sapis, J.C.; Baumes, R.; Bayonove, C. Action des glycosidases exogènes au cours de la vinification, Liberation de l'arôme à partir des précurseurs glycosidiques. J. Int. Sci. Vigne Vin 1990, 24, 133-144.

38. Darriet, P.; Boidron, J.N.; Dubourdieu, D. L’hydrolyse des hétérosides terpéniques du Muscat a Petit Grains par les enzymes périplasmiques de Saccharomyces cerevisiae. Conn. Vigne Vin 1988, 22, 189-195.

39. Mateo, J.J.; di Stefano, R. Description of the $\beta$-glucosidase activity of wine yeasts. Food Microbiol. 1997, 14, 583-591. [CrossRef]

40. Shoseyov, O.; Bravdo, B.A.; Goldman, A.; Cohen, S.; Shoseyov, L.; Ikan, R. Immobilized endo- $\beta$-glucosidase enriches flavour of wine and passion fruit juice. J. Agric. Food Chem. 1990, 38, 1387-1390. [CrossRef] 
41. Dupin, I.; Gunata, Z.; Sapis, J.C.; Bayonove, C.; M'Bairaroua, O.; Tapiero, C. Production of a $\beta$-apiosidase by Aspergillus niger. Partial purification, properties and effect on terpenyl apiosylglucosides from grape. J. Agric. Food Chem. 1992, 40, 1886-1891. [CrossRef]

42. Henick-Kling, T. Control of malo-lactic fermentation in wine, energetics, flavour modification and methods of starter culture preparation. J. Appl. Bacteriol. 1995, 79, 29-37.

43. Maicas, S.; Gil, J.V.; Pardo, I.; Ferrer, S. Improvement of volatile composition of wines by controlled addition of malolactic bacteria. Food Res. Int. 1999, 32, 491-496. [CrossRef]

44. Fleet, G.H. Wine Microbiology and Biotechnology; CRC Press: Boca Raton, FL, USA, 1993.

45. Davis, C.R.; Wibowo, D.; Eschenbruch, R.; Lee, T.H.; Fleet, G.H. Practical implications of malolactic fermentation, a review. Am. J. Enol. Vitic. 1985, 36, 290-301.

46. Grimaldi, A.; McLean, H.; Jiranek, V. Identification and partial characterization of glycosidic activities of commercial strains of the lactic acid bacterium, Oenococcus oeni. Am. J. Enol. Vitic. 2000, 51, 362-369.

47. D’Incecco, N.; Bartowsky, E.; Kassara, S.; Lante, A.; Spettoli, P.; Henschke, P. Release of glycosidically bound flavour compounds of Chardonnay by Oenococcus oeni during malolactic fermentation. Food Microbiol. 2004, 21, 257-266. [CrossRef]

48. Ugliano, M.; Genovese, A.; Moio, L. Hydrolysis of wine aroma precursors during malolactic fermentation with four commercial starter cultures of Oenococcus oeni. J. Agric. Food Chem. 2003, 51, 5073-5078. [CrossRef] [PubMed]

49. Williams, P.J.; Strauss, C.R.; Wilson, B.; Massy-Westropp, R.A. Use of $\mathrm{C}_{18}$ reversed-phase liquid chromatography for the isolation of monoterpene glycosides and nor-isoprenoid precursors from grape juice and wines. J. Chromatogr. 1982, 235, 471-480. [CrossRef]

50. McMahon, H.; Zoecklein, B.W.; Fugelsang, K.; Jasinski, Y. Quantification of glycosidase activities in selected yeasts and lactic acid bacteria. J. Ind. Microbiol. Biotechnol. 1999, 23, 198-203. [CrossRef]

51. Pérez-Martín, F.; Izquierdo-Cañas, P.M.; Seseña, S.; García-Romero, E.; Palop, M.LL. Aromatic compounds released from natural precursors by selected Oenococcus oeni strains during malolactic fermentation. Eur. Food Res. Technol. 2015, 240, 609. [CrossRef]

52. Michlmayr, H.; Nauer, S.; Brandes, W.; Schümann, C.; Kulbe, K.D.; del Hierro, A.M.; Eder, R. Release of wine monoterpenes from natural precursors by glycosidases from Oenococcus oeni. Food Chem. 2012, 135, 80-87. [CrossRef]

53. Mansfield, A.K.; Zoecklein, B.W.; Whiton, R.S. Quantification of glycosidase activity in selected strains of Brettanomyces bruxellensis and Oenococcus oeni. Am. J. Enol. Vitic. 2002, 53, 303-307.

54. Barbagallo, R.N.; Spagna, G.; Palmeri, R.; Restuccia, C.; Giudici, P. Selection, characterization and comparison of $\beta$-glucosidase from mould and yeasts employables for enological Applications. Enzym. Microbiol. Technol. 2004, 35, 58-66. [CrossRef]

55. Yahui, L.; Mingtao, F.; Guoqiang, Z.; Yanlin, L. Assessment of $\beta$-D-glucosidase activity from two typical strains of the lactic acid bacteria, Oenococcus oeni, in China. S. Afr. J. Enol. Vitic. 2012, 33, 144-149.

56. Mesas, J.M.; Rodríguez, M.C.; Alegre, M.T. Basic characterization and partial purification of $\beta$-glucosidase from cell-free extracts of Oenococcus oeni ST81. Appl. Microbiol. 2012, 55, 247-255. [CrossRef] [PubMed]

57. Dong, M.; Fan, M.; Zhang, Z.; Xu, Y.; Li, A.; Wang, P.; Yang, K. Purification and characterization of $\beta$-glucosidase from Oenococcus oeni 31MBR. Eur. Food Res. Technol. 2014, 239, 995-1001. [CrossRef]

58. Michlmayr, H.; Eder, R.; Kulbe, K.D.; del Hierro, A. $\beta$-Glycosidase activities of Oenococcus oeni: Current state of research and future challenges. Mitteilungen Klosterneuburg 2012, 62, 87-96.

59. Li, Y.H.; Fan, M.T.; Zhang, G.Q.; Liu, Y.L. Assessment of $\beta$-D-glucosidase activity from two typical strains of the lactic acid bacteria, Oenococcus oeni, in China. S. Afr. J. Enol. Vitic. 2012, 33, 144-149.

60. Pérez-Martín, F.; Seseña, S.; Izquierdo, P.M.; Martín, R.; Palop, M.L. Screening for glycosidase activities of lactic acid bacteria as a biotechnological tool in oenology. World J. Microbiol. Biotechnol. 2012, 28, 1423-1432. [CrossRef] [PubMed]

61. Bartowsky, E.J.; Borneman, A.R. Genomic variations of Oenococcus oeni strains and the potential to impact on malolactic fermentation and aroma compounds in wine. Appl. Microbiol. Biotechnol. 2011, 92, 441-447. [CrossRef] [PubMed]

62. Bloem, A.; Lonvaud-Funel, A.; de Revel, G. Hydrolysis of glycosidically bound flavour compounds from oak wood by Oenococcus oeni. Food Microbiol. 2008, 25, 99-104. [CrossRef] [PubMed] 
63. Palmeri, R.; Spagna, G. $\beta$-Glucosidase in cellular and acellular form for winemaking application. Enzym. Microb. Technol. 2007, 40, 382-389. [CrossRef]

64. Bloem, A.; Lonvaud, A.; Bertrand, A.; de Revel, G. Ability of Oenococcus oeni to influence vanillin levels. Dev. Food Sci. 2006, 43, 137-140.

65. Grimaldi, A.; Bartowsky, E.; Jiranek, V. A survey of glycosidase activities of commercial wine strains of Oenococcus oeni. Int. J. Food Microbiol. 2005, 105, 233-244. [CrossRef] [PubMed]

66. Du Toit, M.; Engelbrecht, L.; Lerm, E.; Krieger-Weber, S. Lactobacillus: The next generation of malolactic fermentation starter cultures-An overview (2011). Food Bioprocess Technol. 2011, 4, 876-906. [CrossRef]

67. Michlmayr, H.; Brandes, W.; Eder, R.; Schümann, C.; del Hierro, A.M.; Kulbe, K.D. Characterization of two distinct glycosyl hydrolase family $78 \alpha$-L-rhamnosidases from Pediococcus acidilactici. Appl. Microbiol. Biotechnol. 2011, 77, 6524-6530. [CrossRef] [PubMed]

68. Yadav, V.; Yadav, P.K.; Yadav, S.; Yadav, K.D.S. $\alpha$-L-rhamnosidase: A review. Process Biochem. 2010, 45, 1226-1235. [CrossRef]

69. Aryan, A.P.; Wilson, B.; Strauss, C.R.; Williams, P.J. The properties of glycosidases of Vitis vinifera and comparison of their $\beta$-glucosidase activity with that of exogenous enzymes. An assessment of possible applications in enology. Am. J. Enol. Vitic. 1987, 38, 182-188.

70. Chen, D.; Liu, S.Q. Transformation of chemical constituents of lychee wine by simultaneous alcoholic and malolactic fermentations. Food Chem. 2016, 196, 988-995. [CrossRef] [PubMed]

71. Gunata, Z.; Bitteur, S.; Brillouet, J.M.; Bayonove, C.; Cordonnier, R. Sequential enzymic hydrolysis of potentially aromatic glycosides from grape. Carbohydr. Res. 1988, 184, 139-149. [CrossRef]

72. Bitteur, S.; Gunata, Z.; Brillouet, J.M.; Bayonove, C.; Cordonnier, R. GC and HPLC of grape monoterpenyl glycosides. J. Sci. Food Agric. 1989, 47, 341-352. [CrossRef]

73. Voirin, S.; Baumes, R.; Bayonove, C.; M’Bairaroua, O.; Tapiero, C. Synthesis and NMR spectral properties of grape monoterpenyl glycosides. Carbohydr. Res. 1990, 207, 39-56. [CrossRef]

74. Voirin, S.; Baumes, R.; Sapis, J.C.; Bayonove, C. Analytical method for monoterpene glycosides in grape and wine. Part 2. Qualitative and quantitative determination of glycosides in grape. J. Chromatogr. 1992, 595, 269-281. [CrossRef]

75. Skouroumounis, G.K.; Massy-Westropp, R.A.; Sefton, M.A.; Williams, P.J. Synthesis of glucosides related to grape and wine aroma precursors. J. Agric. Food Chem. 1995, 43, 974-980. [CrossRef]

76. Spagna, G.; Andreani, F.; Salatelli, F.; Romagnoli, D.; Casarini, D.; Pifferi, P.G. Immobilization of the glycosidases, $\alpha$-L-arabinofuranosidase and $\beta$-D-glucopyranosidase from Aspergillus niger on a chitosan derivative to increase the aroma of wine. Part II. Enzym. Microb. Technol. 1998, 23, 413-421. [CrossRef]

77. Shoseyov, O.; Bravdo, B.A.; Ikan, R.; Chet, I. Endo- $\beta$-glucosidase from Aspergillus niger grown on monoterpene glycoside containing medium. Phytochemistry 1988, 27, 1973-1976. [CrossRef]

78. Fu-Mian, C.; Pifferi, P.G.; Setti, L.; Spagna, G.; Martino, A. Immobilizzazione di un'antocianasi ( $\beta$-glucosidasi) da Aspergillus niger. Ital. J. Food Sci. 1994, 1, 31-42.

79. Riou, C.; Salmon, J.M.; Vallier, M.J.; Gunata, Z.; Barre, P. Purification, characterization and substrate specifity of novel high glucosidase from Aspergillus orzyae. Appl. Environ. Microbiol. 1998, 64, 3607-3614. [PubMed]

80. Gunata, Z.; Vallier, M.J. Production of highly glucose-tolerant extracellular $\beta$-glucosidase by three Aspergillus strains. Biotechnol. Lett. 1999, 21, 219-223. [CrossRef]

81. Gunata, Z.; Bayonove, C.; Tapiero, C.; Cordonnier, R. Hydrolysis of grape monoterpenyl $\beta$-D-glucosides by various $\beta$-glucosidases. J. Agric. Food Chem. 1990, 38, 1232-1236. [CrossRef]

82. Gunata, Z.; Dugelay, I.; Vallier, M.J.; Sapis, J.C.; Bayonove, C. Multiple forms of glycosidases in an enzyme preparation from Aspergillus niger: partial characterization of an apiosidase. Enzym. Microbiol. Technol. 1997, 21, 39-44. [CrossRef]

(C) 2016 by the authors; licensee MDPI, Basel, Switzerland. This article is an open access article distributed under the terms and conditions of the Creative Commons Attribution (CC-BY) license (http://creativecommons.org/licenses/by/4.0/). 